\title{
BIOPSYCHOSOCIAL DETERMINANTS OF THE QUALITY OF LIFE OF PATIENTS WITH BREAST CANCER: A PATH ANALYSIS EVIDENCE FROM SURAKARTA, CENTRAL JAVA
}

\author{
Sri Nuryati'), Ambar Mudigdo²), Bhisma Murti1) \\ 1)Masters Program in Public Health, Universitas Sebelas Maret \\ 2)Department of Anatomic Pathology, Faculty of Medicine, Universitas Sebelas Maret
}

\begin{abstract}
Background: Breast cancer is the most common cancer among women worldwide. Women are now diagnosed with the disease earlier and live longer. Quality of life has become a well-accepted outcome measure for cancer patients and an integral part of cancer patient management. It has been shown that assessing quality of life in cancer patients could contribute to improved treatment and could even serve as a prognostic factor along with medical parameters. The study aimed to analyze the influence of education level, stage of cancer, social support, and coping strategy, on the quality of life of breast cancer patients.

Subjects and Method: This was a quantitative-qualitative study conducted at Dr. Moewardi Hospital, Surakarta, Central Java, from August to October 2017. A sample of 150 breast cancer patients was selected for the quantitative study by stratified random sampling. A sample of 3 informants were selected for the qualitative study by purposive sampling. The dependent variable was quality of life. The independent variables were education level, stage of cancer, social support and coping strategy. Quantitative data were collected by questionnaire. Social support was measured by Multidimensional Scale of Perceived Social Support (MSPSS) questionnaire. Coping strategy was measured by brief COPE questionnaire. The quality of life was measured by WHOQOL BREF questionnaire. Data qualitative collection was by means in-depth interview. The quantitative data were analyzed by path analysis. Qualitative data was analyzed by Miles and Huberman interactive model.

Results: Quality of life increased with higher education level $(b=8.69, \mathrm{SE}=1.84$, $\mathrm{p}<0.001)$, stronger social support $(\mathrm{b}=1.03, \mathrm{SE}=0.34, \mathrm{p}=0.003)$, good coping strategy $(b=2.07, \mathrm{SE}=0.43, \mathrm{p}<0.001)$. Quality of life decreased with higher stage of cancer $(b=-6.41, \mathrm{SE}=2.94, \mathrm{p}=0.029)$.
\end{abstract}

Conclusion: Quality of life increases with higher education level, stronger social support, good coping strategy, but decreases with higher stage of cancer.

Keywords: social support, coping strategy, quality of life, path analysis

\section{Correspondence:}

Sri Nuryati. Masters Program in Public Health, Universitas Sebelas Maret, Jl. Ir. Sutami 36 A, Surakarta 57126, Central Java. Email: sri.nuryati1985@gmail.com. Mobile: +6282138283802 . 